\title{
Multispecies and multiple anthelmintic resistance on cattle nematodes in a farm in Argentina: the beginning of high resistance?
}

\author{
Miguel E. MEJÍA a , Belisario M. FernándeZ IGARTúA a \\ Enrique E. SCHMIDT ${ }^{\mathrm{b}}$, Jacques CABARET ${ }^{\mathrm{c} *}$ \\ a Veterinary Surgeons, Los Aromos 134, CC 116, CP 6070 Lincoln, Argentina \\ b Dpto Prod. Anim., Fac. Vet. Ciencias Veterinarias, Universidad de La Pampa, Calle 1 esp. 116, \\ CP 6390 General Pico, Argentina \\ c INRA, Bio-Agresseurs Santé Environnement, 37380 Nouzilly, France
}

(Received 26 November 2002, accepted 1 April 2003)

\begin{abstract}
There are very few resistance records on cattle nematodes. South American successive records have been increasing rapidly since the year 2000. In Argentina, increasing dissatisfaction based on the exclusive use of macrocyclic lactones has prompted the use of benzimidazoles in the Pampean region. The studied farm is located in the Argentina humid Pampas and had apparently poor results after anthelmintic treatments. Evaluation of resistance was firstly based on faecal egg reduction after treatment in November 2001 and June 2002 and was complemented with worm counts obtained by necropsy in June 2002. The study reports that the reduction of faecal egg excretion after benzimidazole (reduction 31-79\%) or ivermectin treatments (76-97\%) in November 2001 was insufficient and these poor results were confirmed in June 2002 (benzimidazoles (65$89 \%$ ) and ivermectin (47-77\%)). Several methods for evaluating faecal egg count reduction were performed and yielded different results. A new method based on the estimated faecal egg counts (corrected from the initial faecal egg counts and animal type using a general linear model) was used and gave higher flexibility in the interpretation of putative resistance to anthelmintics. From necropsy results, it could be concluded that Cooperia oncophora was resistant to avermectins and benzimidazoles and that Cooperia punctata, Ostertagia ostertagi and Haemonchus placei were resistant to benzimidazoles. This case of multispecies and multidrug resistance is probably not unique and could reflect the emergence of resistances in Argentina. This emergence is probably due to the intensive use of anthelmintics, the absence of refugia, and the frequent circulation of infected cattle.
\end{abstract}

nematode / cattle / resistance / anthelmintic / Argentina

\section{INTRODUCTION}

Resistance to anthelmintics is a widely described phenomenon in ruminants. Some nematode species and some ruminant species are more prone to develop resistance [5]. An index for nematode resistance was built up and the following ranking of

\footnotetext{
* Correspondence and reprints

Tel.: (33) 2 47427768; fax: (33) 2 47427774; e-mail: cabaret@tours.inra.fr
} 
the host was: goats $>$ sheep $>$ horses $>$ cattle. A similar ranking of nematode resistance was: Haemonchus contortus > Teladorsagia circumcincta $>$ Trichostrongylus sp. > Oesophagostomum sp. > Cooperia sp., among which only Cooperia was recorded mainly in cattle. The resistance in small ruminants has mainly been directed against benzimidazoles (43\% of cases) and then against levamisole or macrocyclic lactones $(23 \%$ each). The apparent lack of anthelmintic resistant nematodes in cattle is probably due to the management systems used with most cattle and the lack of surveys for resistance [6]. With extensive beef grazing or with beef suckler herds a large percentage of the worms are in refugia (not exposed to anthelmintics) [26] and few anthelmintic treatments are used in most parts of the world. These conditions do not favour the appearance of resistance [23]. During the last 15 years in South America, technologies for gastrointestinal control in livestock have been sustained by the large use of broad-spectrum anthelmintics [25]. This is particularly true in the temperate plains of Argentina, where mixed cattlecrop production predominates, management is very intensive, and drugs have been frequently used for many years $[9,10,22$, 25]. Resistance of Cooperia to macrocyclic lactones has been recorded in Argentina [1, $2,13-15,20]$ and treatment using benzimidazoles has regained favour among farmers. In some regions of Argentina, such as in the humid Pampas near Buenos-Aires, a loss of efficacy of macrocyclic lactones is a frequent finding in veterinary practice whereas better results are obtained for benzimidazoles (Mejía, unpublished results). We may expect that farm macrocyclic lactone resistant worms will also become resistant to benzimidazoles when the latter is used extensively. One case of such resistance (based on faecal egg counts and necropsies) to both drugs is presented. We tested several computations since the resistance estimated from faecal egg counts is highly dependent on the way to compute reduction [18].

\section{MATERIALS AND METHODS}

\subsection{Farm location and characteristics}

The farm is located in the Argentina humid Pampas (south of the Cordoba province). Four thousands beef calves that are currently grown from the age of 6 to 20 months were studied. All six-month beef calves were obtained from other farms. In the past they were in part crossbred zebus originating from the north of the country; after the appearance of nematode resistance, Angus crossbreeds were bought, by groups of 70 to 400 from different farms from the near regions. The number of treatments per year was 4 on the farm. Macrocyclic lactones were used more than benzimidazoles before 2001 ( 3 macrocyclic lactones and 1 benzimidazole), but thereafter benzimidazoles were preferred ( 3.5 benzimidazoles and 0.5 macrocyclic lactones).

\subsection{Resistance based on faecal egg counts}

The faecal egg counts were performed using a modified McMaster technique (flotation liquid being an $\mathrm{NaCl}$ saturated solution). Each egg counted represented 20 eggs/gram of faeces. A first evaluation was done in November 2001. Five groups of 10 calves were used either as the control or were treated with fenbendazole (per os Axilur ${ }^{\circledR} 7.5 \mathrm{mg} / \mathrm{kg}$ bodyweight or intraruminally injected Bendax ${ }^{\circledR} 7.5 \mathrm{mg} / \mathrm{kg}$ b.w.), ivermectin (Ivomec $^{\circledR}$ or Rosenbusch ${ }^{\circledR}$, $200 \mu \mathrm{g} / \mathrm{kg}$ b.w., both injected). Axilur ${ }^{\circledR}$ and Ivomec ${ }^{\circledR}$ are the international brands whereas Bendax ${ }^{\circledR}$ and Rosenbusch ${ }^{\circledR}$ are generic drugs prepared in Argentina. Treatment was given after $24 \mathrm{~h}$ of the diet in order to obtain a maximum efficacy [16]. The faecal egg counts were done on the day of treatment and 12 days later. A second evaluation in June 2002 involved 3 groups (14 to 15 calves each): a control and two treated groups (Axilur ${ }^{\circledR}$ and 
Ivomec $^{\circledR}$ ). The conditions for treatment were as in the first evaluation.

\subsection{Resistance based on necropsies}

In June 2002, six calves were necropsied in order to determine which species were involved in resistance. Two were treated with Axilur ${ }^{\circledR}$, two with Ivomec ${ }^{\circledR}$, and two remained as the untreated controls. The necropsies were done according to the technique of Suarez [24], and the 1/10th aliquot was examined. The identification of worms was done according to Suarez [24].

\subsection{Statistical methods}

The methods to evaluate flock faecal egg count reduction (FECR) are numerous and may yield very different figures. We used:

(1) after treatment evaluation in the control and treated hosts: FECR $=100(1-$ [T2/C2]) where T2-treated and C2-control are the arithmetic mean of eggs per gram of faeces (epg), 10 to 14 days after treatment (WAAVP method [7]);

(2) before and after treatment evaluation in treated hosts (without control group): FECR $=100(1-[\mathrm{T} 2 / \mathrm{T} 1])$ where $\mathrm{T} 2$ is the post treatment and T1 is the pretreatment arithmetic mean of the epg (in [18]);

(3) Dash formula, before and after treatment evaluation in treated and control hosts: FECR $=100(1-[\mathrm{T} 2 / \mathrm{T} 1] \times[\mathrm{C} 1 / \mathrm{C} 2])$ where $\mathrm{T} 2$ and $\mathrm{T} 1$ are pre- and post-treatment arithmetic means of the epg in treated groups and $\mathrm{C} 1$ and $\mathrm{C} 2$ are pre- and posttreatment arithmetic means of the epg in the controls (in [18]);

(4) Presidente formula (in [18]) is based on the Dash formula where the geometric instead of the arithmetic means are used;

(5) A general linear model-GLM (EPG after treatment depending on initial EPG and type of treatment) based on natural logarithm transformed data (to stabilise variance) was also used since it permitted to unambiguously evaluate the statistical differences between batches, due to the treatment only. GLM allows much greater flexibility than standard analysis of variance-ANOVA or analysis of covarianceANCOVA procedures by allowing one to freely combine quantitative and qualitative factors. It also handles the balanced and unbalanced ANOVA design by providing automatic adjustments for an unequal cell size (the regression evaluation was used). FECR based on the estimated geometric means using the linear general model was also calculated; it is a new method for estimating FECR. This analysis can be summarised as follows: (i) after-treatment faecal egg counts +1 were Neperian logarithm transformed; (ii) the factors to be included as the covariable were the initial faecal egg count +1 Neperian logarithm transformed, month (November or June), type of treatment (generic or standard commercial preparation); (iii) after treatment estimated values from GLM were obtained, back-transformed using exponential function (equivalent to the geometric mean); and finally (iv) the faecal egg count reduction was calculated on the estimated after treatment and control means (means corrected from covariable effects).

\section{RESULTS}

\subsection{Resistance based on FECR (Tab. I)}

FECR is shown in Table I. The efficacy of fenbendazole and ivermectin ranged respectively from 51 to $79 \%$ and 47 to $95 \%$ depending on the computation and period of investigation. The computation methods yielded fairly different results (65 to $89 \%$ for fenbendazole in June 2002 for example). The GLM analysis showed that there was no significant difference between the generic and original drugs. The efficacy of benzimidazoles in the November experiment was not really high since the statistical difference between the treated and control calves ranged from $p=0.08$ (Axilur ${ }^{\circledR}$ ) to 
Table I. Faecal egg count (in egg per gram, EPG) reduction (FECR) in fattening beef calves in November 2001 and June 2002 using a benzimidazole (fenbendazole: $7.5 \mathrm{mg} / \mathrm{kg}$ body weight) and a macrocyclic lactone (ivermectine: $200 \mu \mathrm{g} / \mathrm{kg}$ b.w.).

\begin{tabular}{lcccc}
\hline & & \multicolumn{2}{c}{ EPG (Range) } & FECR $^{\mathrm{a}}(\%)$ \\
\cline { 3 - 4 } & & Day 0 & Day 12 & \\
\cline { 3 - 4 } November 2001 & & & \\
$(n=10)$ & Axilur $^{\circledR}$ & $176(80-500)$ & $58(0-240)$ & $61,67,67,79,51$ \\
$(n=10)$ & Bendax $^{\circledR \mathrm{b}}$ & $166(80-360)$ & $104(0-40)$ & $31,36,37,67,41$ \\
Ivermectin & & & & \\
$(n=10)$ & Ivomec $^{\circledR}$ & $156(80-260)$ & $12(0-40)$ & $92,92,92,95,80$ \\
$(n=10)$ & Rosenbusch $^{\circledR \mathrm{b}}$ & $154(80-260)$ & $20(0-140)$ & $87,87,87,97,76$ \\
Untreated control & & $154(80-260)$ & $150(0-280)$ & \\
$(n=10)$ & & & & \\
June 2002 & & & & \\
Fenbendazole $(n=14)$ & Axilur $^{\circledR}$ & $473(220-1280)$ & $64(0-300)$ & $80,80,87,89,65$ \\
Ivermectin $(n=14)$ & Ivomec $^{\circledR}$ & $435(280-1220)$ & $149(0-640)$ & $54,50,66,77,47$ \\
Control $(n=15)$ & & $476(240-1340)$ & $324(100-760)$ & \\
\hline
\end{tabular}

a FECR calculated using five methods (1. Coles et al. 1992 [7]; 2. before and after treatment evaluation, in treated hosts without the control group (in [18]); 3. Dash formula (in [18]); 4. Presidente (in [18]); 5 . and a new one based on the means estimated by the least square methods in a general linear model).

$\mathrm{b}$ Generic drugs prepared in Argentina.

$p=0.11\left(\right.$ Bendax $\left.^{\circledR}\right)$. Fenbendazole efficacy was higher in June 2002 than in November 2001. An opposite result was observed for ivermectin. Resistance to ivermectin appeared in 2000 (data not shown) and ivermectin was not used in 2001 and 2002 except for an evaluation on a limited number of cattle.

\subsection{Resistance as established on necropsy results (Tab. II)}

H. place $i$ was well controlled with ivermectin but the efficacy of fenbendazole was very low. $O$. ostertagi was removed by ivermectin but fenbendazole was poorly efficient (the Newman-Keuls test showed significant differences $(p=0.01)$ between ivermectin and fenbendazole treated calves; fenbendazole and control calves harboured similar worm burdens). No significant difference could be shown for C. oncophora, which indicated that both treatments were not efficient. For $C$. punctata, significant differences $(p=0.01)$ were evidenced (a significant difference between the ivermectin treated calves versus the control and fenbendazole treated calves): only ivermectin was efficient.

\section{DISCUSSION}

The establishment of resistance is difficult to assess on the sole measure of FECR since it depends strongly on the experimental procedure (with or without controls) and the evaluation of the reduction [18]. The Presidente method yielded the best calculated efficacies $(95 \%$ and $97 \%$ for Ivomec $^{\circledR}$ and Rosenbusch ${ }^{\circledR}$ 
Table II. Worm burden obtained necropsies from untreated and treated herds (June 2002).

\begin{tabular}{lccc}
\hline Strongyle species & $\begin{array}{c}\text { Untreated } \\
\text { control } \\
(2 \text { calves })\end{array}$ & $\begin{array}{c}\text { Benzimidazole } \\
\text { Axilur } \\
(2 \text { calves })\end{array}$ & $\begin{array}{c}\text { Macrocyclic lactone } \\
\text { Ivomec }^{\circledR} \text {-injected } \\
(2 \text { calves })\end{array}$ \\
\hline Haemonchus placei & $100-100$ & $0-207(-4)^{\mathrm{a}}$ & $0-0(100)$ \\
Ostertagia ostertagi & $1957-7324$ & $2019-3567(39)$ & $1-2(100)$ \\
Cooperia oncophora & $4032-19264$ & $1704-16614(21)$ & $5800-5900(50)$ \\
Cooperia punctata & $4368-15136$ & $696-6786(62)$ & $0-0(100)$ \\
Trichostrongylus axei & $0-200$ & $0-0(100)$ & $0-0(100)$ \\
All species reduction $(\%)$ & & 40 & 78 \\
\hline
\end{tabular}

${ }^{a}$ Number of worms (efficacy in \%). Efficacy $=100 \times($ number of worms in the untreated controls-number of worms in the treated calves) / (number of worms in the untreated controls).

respectively) and thus ivermectin could be considered as non resistant in the first trial (see Tab. I). The method we proposed using a reduction based on a least square means (evaluated from a general linear model geometric means) indicated that in all cases, efficacy was low and hence resistance to benzimidazole and ivermectin existed in the worm community. The least square estimation in relation to the treatment was corrected from the initial faecal egg count. This method is flexible and could possibly incorporate other sources of variations such as the type of animal or type of drenching (per os, pour on, etc.). The reduction of worm burden was low for both drugs (see Tab. II) but was not in the same magnitude as established on the FECR (40 vs. $87 \%$ and 78 vs. $66 \%$ for benzimidazole and ivermectin, respectively). The differences in evaluation is due to the fact that in the estimated geometric mean methods, differences in efficacy are only due to the main factor (treatment) corrected for initial egg output. The discrepancy was particularly important for the benzimidazole treated group, possibly due to the ovicidal activity of these drugs. This means that FECR probably overscores the actual resistance for benzimidazoles. A similar phenomenon has been reported in New-Zealand when using the ivermectin treatment on Cooperia: FECR indicated a reduction of $44 \%$ whereas no worm reduction was demonstrated [8]. The species involved in resistance (Cooperia or Ostertagia) may also play a role on the efficacy evaluations: Cooperia sp. lay much more eggs than $O$. ostertagi and FECR evaluations are probably more efficient for the former species. All considered, a conclusion on the resistance to both drugs could be drawn in our case.

Resistance in cattle nematodes has remained limited in most countries [6], except in New-Zealand [3, 12, 17, 19], Argentina and Brazil. Selective pressure in both South American countries is high due to numerous treatments, absence of refugia, intense immigration of new animals with possibly resistant helminths. Resistance to ivermectin has been widely documented in Cooperia in New-Zealand (it could concern $89 \%$ of the farms [18]), South America (Argentina: [1, 2, 13-15, 20], and possibly [22]; Brazil: [11, 21], ( $20 \%$ of the farms), although it has not always been assessed at the nematode species level. Resistance to benzimidazoles is less frequent $[21,27,28]$ and may concern Ostertagia or Haemonchus. Resistance to levamisole has been rarely described $[4,27]$. In our case, multispecies resistance to benzimidazoles (Haemonchus placei, Ostertagi ostertagi, Cooperia oncophora, Cooperia punctata) was associated with 
Cooperia oncophora resistance to avermectins. Haemonchus placei resistance to benzimidazoles has already been recorded by Pinheiro and Echevarria in Brazil [21]: the efficacy of oxfendazole and albendazole ranges from 60 to $80 \%$. Such a resistance has already been suspected in the subarid Pampas [22]: farms with a history of frequent benzimidazole treatments have a higher percentage of $H$. placei in the worm community and it is thought to be introduced from northern tropical areas of Argentina into the Pampas. Conversely $O$. ostertagi resistance is probably a locally acquired resistance.

Farmers in the affected farms in the humid Pampas are dissatisfied with the use of ivermectin, and they changed from 4-5 ivermectin treatments to only one, needed for control of ectoparasites. At the same time they replaced other scheduled treatments with benzimidazoles (data from 10 farms: Mejía, unpublished). The farmers are not eager to switch to levamisole (since it is poorly efficient on inhibited larvae of $O$. ostertagi) and intend to use benzimidazoles more frequently in the future as shown from the above data. If the situation recorded on the studied farm is representative of other farms, one may question the switch to benzimidazole use and consider: (i) the use of levamisole when Cooperia sp. are the most prevalent, (ii) possibly consider the simultaneous use of levamisole and ivermectin (at periods when ectoparasites are a problem), levamisole and benzimidazole (when adult $O$. ostertagi is the main problem), (iii) ivermectin when inhibited $O$. ostertagi are present. The difficulty to choose an anthelmintic, the necessity to associate several drugs will be a current issue in the future and should not be the only mean to control internal parasites. The use of safe pastures and the use of treatments when needed on a weight gain or faecal egg count basis is a necessity. The application of such a programme should be integrated in the different farming managements existing in the humid Pampas.

\section{ACKNOWLEDGEMENTS}

We are grateful to Chilpe S.A. who gave us the opportunity to perform FECR tests and offered the calves for necropsy. We are indebted to Ing. Osvaldo Marré (h) for his trust, and to "Chanta" Ledesma and his team for their help in the field. The method for calculating resistance using the general linear model can be implemented from several softwares. We used Simstat for Windows 1996 and are able to help naive users for evaluating resistance on GLM estimated means.

\section{REFERENCES}

[1] Anziani O.S., Gugliermone A.A., Zimmermann G., Vazquez R., Suarez V.R., Resistencia a las avermectinas de bovinos parasitados por Cooperia spp., Veterinaria Argentina 164 (2000) 280281.

[2] Anziani O.S., Zimmermann G., Guglielmone A.A., Vazquez R., Suarez V., Avermectin resistance in Cooperia punctata in cattle in Argentina, Vet. Rec. 149 (2001) 58-59.

[3] Bisset S.A., Brunsdon R.V., Forbes S., Efficacy of a topical formulation of ivermectin against naturally acquired gastro-intestinal nematodes in weaner cattle, N.Z. Vet. J. 38 (1990) 4-6.

[4] Borgsteede F.H.M., Further studies with a strain of Ostertagia ostertagi resistant to morantel tartrate, Int. J. Parasitol. 21 (1991) 867-870.

[5] Cabaret J., Anthelmintic resistance in goats: from fiction to facts, Proc. 7th Int. Conf. on goats, France, 2000, pp. 793-794.

[6] Coles G.C., Cattle nematodes resistant to anthelmintics: why so few cases? Vet. Res. 33 (2002) 481-489.

[7] Coles G.C., Bauer C., Borgsteede F.H., Geerts S., Klei T.R., Taylor M.A., Waller P.J., World association for the advancement of Veterinary parasitology (W.A.A.V.P.) methods for the detection of anthelmintic resistance in nematodes of veterinary importance, Vet. Parasitol. 44 (1992) 35-44.

[8] Coles G.C., Stafford K.A., MacKay P.H.S., Ivermectin-resistant Cooperia species from calves on a farm in Somerset, Vet. Rec. 142 (1998) 255-256.

[9] Costa J., Mejía M., Martinez E.F., Cabaret J., El control de la gastroenteritis verminosa en 
la Pampa húmeda (Argentina) bajo condiciones de campo, entre 1979 y 1987: resultados, Technicrea, 1989, pp. 3-17.

[10] Costa J.C.A., Mejía M.E., Cabaret J., Ganancias de pesos vivos de novillos y vaquillonas de la pampa húmeda en relación con el parasitismo por estrongilidos digestivos, ITEA 70 (1987) 38-47.

[11] Echevarria F.A.M., Pineihro A.C., Efficacy of anthelmintics in cattle, 18th International Conference of the WAAVP, 26-30 August, Stresa, Italy, Abstract No. 147, 2000.

[12] Familton A.S., Mason P., Coles G.C., Anthelmintic resistant Cooperia species in cattle, Vet. Rec. 149 (2001) 719-720.

[13] Fiel C.A., Saumell C.A., Steffan P.E., Rodríguez E.M., Resistance of Cooperia to ivermectin treatments in grazing cattle of the humid Pampa, Argentina, Vet. Parasitol. 97 (2001) 211-217.

[14] Fiel C., Anziani O., Suarez V., Vazquez R., Eddi C., Romero J., Caracostantogolo J., Saumell C., Mejía M., Costa J., Steffan P., Resistencia antihelmintica en bovinos: causas, diagnostico y profilaxis, Veterinaria Argentina 18 (2001) 21-33.

[15] Fiel C.A., Saumell C.A., Steffan P.E., Rodríguez E.M., Salaberry G., Resistencia de los nematodes trichostrongylideos - Cooperia y Trichostrongylus - a tratamientos con avermectinas en bovinos de la Pampa Húmeda, Argentina, Revista de Medicina Veterinaria, 81 (2000) 310-315.

[16] Hennessy R.J., Modifying the formulation or delivery mechanism to increase the activity anthelmintic compounds, Vet. Parasitol. 72 (1997) 145-152.

[17] Jackson R.A., Townsend K.G., Pyke C., Lance D.M., Isolation of oxfendazole resistant Cooperia oncophora in cattle, N. Z. Vet. J. 35 (1987) 187-189.

[18] Kochapakdee S., Pandey V.S., Pralomkarm W., Choldumrongkul S., Ngampongsai W., Lawpetchara A., Anthelmintic resistance in goats in southern Thailand, Vet. Rec. (1995) 124-125.
[19] McKenna P.B., Resistance to benzimidazole anthelmintics in cattle in New Zealand, N. Z. Vet. J. 39 (1991) 154-155.

[20] Mejía M., Bovine nematodes resistance to avermectins in Argentina, 18th International Conference of the World Association for the Advancement of Veterinary Parasitology, 26-30 August, 2001, Stresa, Italy, Abst. No. 18.

[21] Pinheiro A.C., Echevarria F.A.M., Susceptibilidade de Haemonchus spp. em bovinos ao tratamiento anti-helmintico com albendazole o oxfendazole, Pesquisa Veterinaria Brasileira, 10 (1990) 19-21.

[22] Schmidt E.E., Diversité spécifique chez les helminthes des bovins: méthodes d'approche et facteurs de variations, Thèse de Sciences, 2000, Créteil, Université Paris XII.

[23] Silvestre A., Leignel V., Berrag B., Gasnier N., Humbert J.F., Chartier C., Cabaret J., Sheep and goat nematode resistance to anthelmintics: pro and cons among breeding management factors, Vet. Res. 33 (2002) 465-480.

[24] Suarez V.H., Diagnostico de las parasitosis internas de los rumiantes en la región de invernada, interpretación y técnicas. Boletín de divulgación técnica número 56, 1997.

[25] Suarez V.H., Helminthic control on grazing ruminants and environmental risks in South America, Vet. Res. 33 (2002) 563-573.

[26] van Wyk J.A., Refugia-overlooked as perhaps the most potent factor concerning the development of anthelmintic resistance, Onderstepoort J. Vet. Res. 68 (2001) 55-67.

[27] Williams J.C., Brossard S.D., Comparative efficacy of levamisole, thiabendazole, and fenbendazole against cattle gastrointestinal nematodes, Vet. Parasitol. 58 (1995) 83-90.

[28] Williams J.C., De Roas A., Nakamura Y., Loyacano A.F., Comparative efficacy of ivermectin pour-on, albendazole, oxfendazole, and fenbendazole against cattle gastrointestinal nematodes, Vet. Parasitol. 73 (1997) 73-82. 